\title{
Developing the Capacity of School Management to Build Understanding of Vision and Mission
}

\author{
Dwi Sukaningtyas \\ Postgraduates of Educational Administration Study Program \\ Universitas Pendidikan Indonesia, UPI \\ Bandung, Indonesia \\ dwi.suka@yahoo.com
}

Udin Syaefudin Sa'ud

Postgraduates of Educational Administration Study Program

Universitas Pendidikan Indonesia, UPI

Bandung, Indonesia

usaud@upi.edu

\begin{abstract}
In many schools, the vision mission just "exist" and not become a guideline especially implementation of learning. The school just execute school routine without knowing the meaning of implementation. This is unfortunate, because the vision and mission is a unique destination that covers the activity and can be utilized as the power of quality of the service organization. How is the capacity of school management in developing the vision and mission? The goal of the research is to describe and analyze the capacity of school management in developing the vision and mission. This study used a qualitative approach with case studies. Data collection methods used are interviews, observation, and study of the document/artifact. The validity of the data is done with credibility, transferability, dependability, and confirmability. The results shows that schools which establish vision and mission based on noble values of the founders have a strong base for the development.
\end{abstract}

Keywords-school vision, school mission, the capacity of school management

\section{INTRODUCTION}

Since eight National Education Standards have been applied, all schools include vision and mission as the ultimate goal of education. In planning the programs, schools need to formulate and determine the vision, mission and objectives of the school and the development.

Vision as the ultimate goal of the school is achieved in relatively long term. While the mission is the medium-term objective specified in the next regular school goals to be achieved each year of school operations. The vision and mission of the school is a guideline that underlies the entire program at the school, as well as all the activities and programs of the school. Several studies of the essence of the vision and mission of an organization or institution have been done. The vision is more strongly linked to the performance of a stronger organization [11]. That, the significant effects of school improvement and organizational change centered on the development of shared vision and mission to progress [8]. When a leader or manager is able to cooperate with a team based on the shared vision, then their work will reflect the

\author{
Djam'an Satori \\ Postgraduates of Educational Administration Study Program \\ Universitas Pendidikan Indonesia, UPI \\ Bandung, Indonesia \\ djamansatori@yahoo.com
}

degree of harmony and transparency [1]. That, the vision of the school is one of the three essential elements/parts that there should be exist to improve the school. Two other elements are building the capacity and leadership [22].

Several studies mention the following. That, the vision, mission, goals, and values which are expected to be reflected in the daily practices of learners is only be remembered. The vision, mission, goals, and values built through good practice are supposedly be the key to improve the quality of schools [8]. The daily practice can be applied continuously to consequently improve school achievement and education of the students. Other studies apply vision in a broader scope as the vision for education in a country. That incompatible policy leads to less government support politically [22]. Meanwhile, building a shared vision for education reflects the level of transparency that is beneficial to all parties [1].

In fact, many schools simply make the school's vision simply "exist" and neither as guideline education management. The next thing that happens, the quality of education goes as if it has no direction, the school simply carrying out the routine without knowing the meaning of the implementation. Worse yet, the results of all-round "instant" education, the students learn just to get grades, educators teach only limited material that needs to be taught without meaning. This is not in line with what is implicitly stated in the Act No. 20 of 2003 [25], article 1 and 3 , that mentioned the function and purpose of education as a "whole".

What causes the problems described above occur? The purpose of education and learning that is reflected in the vision and mission of the school has not been fully achieved. The same case goes with the achievement of the ability to master knowledge and problematic attitudes. Some previous studies also assume that it is possibly happened because of the capacity of schools that has not been empowered maximally.

That, "Schools that do not have the capacity or quite clear capability would have trouble in making various efforts for continuous improvement effectively." The third aspect of the 
school's capacity is happening still in the stage of implementation and does not have a clear direction of policy program. Capacity that belongs to the school is not geared to the superior and focus on specific objectives [23]. While in a preliminary study research assumes that "... the school had problems in school management capacity, particularly related to the malfunction of roles and functions of teachers and in completing tasks and solving problems faced by the school" [24].

Improving the capacity of schools has been carried out for several needs, they are, school's capacity should be utilized maximally for the successful implementation of school-based management (SBM). School capacity covering four aspects related to the implementation of school-based management in the context of the decentralization of education at the basic education level. The purpose of this study was to obtain data and information regarding to school capacity maps related to four aspects: the school budget, human resources and school infrastructure, school management, as well as the participation of parents [16][15]. In the other study mentioned that improving quality of education is needed to achieve prominent schools or to improve the quality of schools [23][24].

The vision and mission is a unique destination that covers the activity and can be utilized as the power quality of the service organization. How is the school management capacity in developing the vision and mission? That question becomes the basis of the discussion in this study.

\section{METHOD}

This study used a qualitative approach case study type; it is multi case because there are two study sites. Methods of collecting qualitative data through interviews, observation, study of documents and artifact. Preparation for this approach was done by setting up the research framework that contains the focus of the study, the data collection methods used, and the participants involved.

Then the research framework is elaborated in accordance to the instrument containing the aspects studied. Next, the instruments were elaborated in the form of detailed as the guidelines to all methods of data collection. Each contained a guide to interviews, observation and document/artifact.

The process of data collection, processing, and display the results of a qualitative approach were carried out approximately eight months long. This sequence of stages was intended to examine the condition of school management capacity. Detailed data about the condition of school management capacity was evaluated and analyzed as a basis to determine the pattern of developing the capacity of school management in building the vision and mission.

Observations were conducted to determine the routine activities undertaken related to the school community programs that were intended to build the vision and mission. Besides, the researchers also made observations on the meetings in discussing and establishing policies, or guiding teachers and education personnel. Interviews were conducted based on the outline instrument of literature review in the form of questions with open answers. Interviews were conducted with one or more participants in the form of focus group discussion (FGD).
FGD was conducted on a program design and evaluation session, because at that stage the teachers and the education personnel do teamwork. Interviews were also conducted in unstructured or informal techniques "conversational"/daily conversation. Participants involved in the interview were selected through the snowball method. Researchers determine the first participant as the key informants, and then he/she selected the next participants. The context of this study is related to the basic values of the institutions that were usually built early by the founders of the school. In connection with that context, the researchers chose the founder or the chairman of the foundation and the school principal the key informants for each school. The other participants involved were the educators and education personnel, students/prospective students, and parents/ expectant parents. Each of these various roles involved in the administration of the school. Selection by this method was expected to produce a sufficient range of sample to describe the conditions in a variety of perspectives. The researchers were the main instrument (key instrument). Researchers also took on the role as participant observers.

The study of the school documents was done by collecting relevant school documents to the context of the research. These documents were in the form of school development plan, the annual work plan, the school activities document, learning documents (teaching planning, implementation agenda, as well as plans and assessments), the budget plan of the school, and so on. While the artifacts studies done by documenting them in the form of images. The collection was intended to connect the existence of the artifact with their benefits in the process of developing the capacity of school management. The entire process of data collection was done in a manner that based on the qualitative data collection procedures.

The validity of the data was tested with the degree of credibility, transferability, dependability, and conformability. Based on the data collection, researchers got the rational conditions that occur in the field. The description of the condition was the result of the rational credibility (internal validity) with members checking and triangulation techniques. Member checking was the result of interpretation and conclusion of the researchers' data presented to participants for approval. While triangulation was done by comparing and checking the level of trust of the information obtained from multiple sources (participants involved in formal and informal interviews), methods for collecting the data (such as interviews, observation, and study of document/artifact). The data collected were analyzed qualitatively, the analysis of a single case and multicast.

\section{RESULTS AND DISCUSSION}

The study is conducted by researchers to answer research questions; how do schools developing the management capacities in build the vision and mission?

The data were collected through in-depth interviews and daily, observation, and study of the document/artifact conducted at two location of the school, Nasima high school (school A) and Sultan Agung 1 high school (school B) Semarang. At each location, participants involved interviews including: board/management institutes, principals, viceprincipals, and educators. Furthermore, the results of the 
interviews between participants were triangulated by the sources, then also been triangulated with other data collection methods such as observation and study of the documents/ artifacts, in order to obtain reflection or relatively the same data interpretation.

The assessment focused on the research question consisted of two aspects studied, i.e. characteristics and indicators of achievement of the vision and mission. Here are the results of meaning at both locations according to the aspects of the code.

Table 1. Results of Data Collection

\begin{tabular}{|c|c|}
\hline \multicolumn{2}{|c|}{ Rational / Conditions Empirical } \\
\hline School A & School B \\
\hline \multicolumn{2}{|c|}{$\begin{array}{l}\text { Aspect Code : RMa01.01.01 } \\
\text { Aspect }: \text { characteristics of achievement of the vision and mission }\end{array}$} \\
\hline $\begin{array}{l}\text { - Formulation of the mission and } \\
\text { vision statements (especially } \\
\text { vision) based on the concerns of } \\
\text { the founders who feel the } \\
\text { impact of education in the past } \\
\text { that it is less able to equip the } \\
\text { nation's children with the } \\
\text { quality of scientific competence } \\
\text { and life skills, noble morality, } \\
\text { as well as the formation of } \\
\text { character and identity as a } \\
\text { human being of Indonesia. } \\
\text { - Pure vision statement was } \\
\text { developed by the founders, } \\
\text { while the mission statement has } \\
\text { been constructed through } \\
\text { realignment in } 2008 \text {, together } \\
\text { with the institutions and } \\
\text { schools. } \\
\text { - Average teachers/staff do } \\
\text { not/less memorize the sentences } \\
\text { of vision and mission statement } \\
\text { completely. } \\
\text { - Average teacher/staff can } \\
\text { mention the core of the sentence } \\
\text { of vision statement, and are able } \\
\text { to interpret it. } \\
\text { There is a document that } \\
\text { mention the meaning of mission } \\
\text { and vision statements. } \\
\text { The documents has been given } \\
\text { to teachers/staff (pocket book). } \\
\text { But, It is not yet accustomed to } \\
\text { be a means of 'reminder' for } \\
\text { them. }\end{array}$ & $\begin{array}{l}\text { - Formulation of the mission and } \\
\text { vision statements (especially } \\
\text { vision) based on the 'khitah' of } \\
\text { the founder in the 50s. } \\
\text { - The grand design of the vision } \\
\text { statement (core) was first } \\
\text { conceived and formulated by a } \\
\text { team of the institutions. Next, in } \\
\text { conceiving the mission statement } \\
\text { (vision also), a team of educators } \\
\text { (principals) was involved. The } \\
\text { involvement of a team of } \\
\text { educators was also included in } \\
\text { the preparation of the } \\
\text { characteristics/indicators of } \\
\text { achievement, which further } \\
\text { developed as a school strategic } \\
\text { plan for a minimum period of '15 } \\
\text { years'. } \\
\text { - Average teachers/staff do not/ } \\
\text { less memorize the sentence of } \\
\text { vision and mission statement } \\
\text { completely. } \\
\text { Average teachers/staff can } \\
\text { mention the core of the sentence } \\
\text { vision statement, and is able to } \\
\text { interpret it. } \\
\text { While the mission phrase, they } \\
\text { also do not/less memorize. } \\
\text { However, as educators, they are } \\
\text { on their way to reach } \\
\text { memorizing it. } \\
\text { The meaning of the vision and } \\
\text { mission of the school is not } \\
\text { contained in the document. }\end{array}$ \\
\hline \multicolumn{2}{|c|}{$\begin{array}{l}\text { Aspect Code : RMa01.01.02 } \\
\text { Aspect : Indicators of achievement of the vision and mission }\end{array}$} \\
\hline $\begin{array}{l}\text { - Characteristics which are exist } \\
\text { in the vision and mission } \\
\text { statements have not been } \\
\text { broken down into indicators of } \\
\text { achievement, but detail of the } \\
\text { characteristics is existing in the } \\
\text { form of a flowchart. } \\
\text { - Details of the mission have not } \\
\text { been written to the school's } \\
\text { objectives. }\end{array}$ & $\begin{array}{l}\text { - Characteristics which are exist in } \\
\text { the vision statement have been } \\
\text { broken down into indicators of } \\
\text { achievement. } \\
\text { - The details have been written as } \\
\text { a mission school goals. } \\
\text { - Characteristic of this vision is } \\
\text { then translated into several } \\
\text { school programs. }\end{array}$ \\
\hline
\end{tabular}

Table 1. Cont.

\begin{tabular}{|c|c|}
\hline \multicolumn{2}{|c|}{ Rational / Conditions Empirical } \\
\hline School A & School B \\
\hline $\begin{array}{l}\text { Mission and vision statements, } \\
\text { as well as complete written } \\
\text { goals on school documents } \\
\text { (school work plan/work plan } \\
\text { and budget of the school). } \\
\text { - In addition to documents, } \\
\text { artifacts vision and mission } \\
\text { statement in almost every room } \\
\text { in the school environment. } \\
\text { - Understanding of the } \\
\text { characteristics of the vision and } \\
\text { mission is given in a special } \\
\text { forum. But it is only tentative, } \\
\text { there was one/two times, and it } \\
\text { is not performed periodically/ } \\
\text { continuously. }\end{array}$ & $\begin{array}{l}\text { Mission and vision statements, } \\
\text { as well as complete written goals } \\
\text { on school documents (school } \\
\text { work plan/work plan and budget } \\
\text { of the school), including its } \\
\text { characteristics. } \\
\text { - In addition to documents, } \\
\text { artifacts vision and mission is } \\
\text { hardly found in the school } \\
\text { environment. } \\
\text { - Understanding of the } \\
\text { characteristics of the vision and } \\
\text { mission is not specifically } \\
\text { granted in the forum for teachers } \\
\text { and staffs. Internal meeting } \\
\text { forum initiated by the } \\
\text { institutions was focus more on } \\
\text { the professional development. } \\
\text { - Indicators of achieving the } \\
\text { vision and mission of the school } \\
\text { were written on the document. }\end{array}$ \\
\hline
\end{tabular}

Both the institution has the same way in developing a vision and mission statement based on the philosophy adopted by the institution. School B adheres to the values of the Islamic religion, and the basis of the vision and mission is taken from the Quran and Hadith. Meanwhile, school A adheres to the values of the Nationalist and religion (Islam), then the basis of the vision-mission obtained by the founder of a long journey of nation/country influenced by local culture and the development of education in Indonesia, and it is mated with the values of Islam espoused in the development of Islam in Indonesia.

Vision is the ultimate goal of the school, as the long-term goals of the organization. Vision has been regarded as an important component of effective leadership for over 20 years [4]. Both schools consider vision as an important statement, so that the noble values (philosophy) adopted by the institution becomes the basis in drafting a vision statement. Not only has the vision, the mission statement of the school has also been prepared based on these values. The mission is understood as the basic goals of the organization service. It is the mission that distinguishes the form of the services between organizations. The mission is a statement that describes the service to the customer. Hence, any particular statement (vision-mission) for the organization/school must be something special/unique/ specific to their beliefs [2][7].

Not enough just becoming something special, human education system must be built with a strong foundation. Education is not only based on accumulated knowledge, to the best, it is incomplete. The complete basic derived from the Holy Book, that the revelation of God is the foundation of all knowledge [6]. That vision is derived or arising from the proximity of humans with the Creator, to know and meditate on His Word, to be what the Creator wants [3][7][18]. On the condition of empirical researchers encountered, by both institutions, the vision and mission of the school has been compiled based on the values espoused in the Holy Book. In school B, the sentence vision "... form generation Khaira Ummah" is a statement that back in the early thought the 
founders in 1950, who took the basic vision statement of the letters AL-Quran is a letter Ali Imron paragraph 110. While school A, one of the basic mission and vision statements are hadith the Prophet "Educate children (descendants) because they would face an age not like your whole life."

Mission and vision statements at both schools were prepared early by involving the organization personnel. In fact one of them stating 'check' to the school's vision can be interpreted and implemented together. Parties involved in the preparation of the mission and vision statements at private institutions, generally involving the institutions and schools. Parties concerned agencies to entrust the grand design that contains the basic philosophy of drafting the vision and mission. Meanwhile, the school is obliged to translate the sentence statement. In the essence, the meaning of the vision and mission statement is in accordance with the grand design of the institution.

Vision-mission statement should be drafted by team or collective, that those concerned will implement it. It is intended that these people understand the reasons for the design of vision-mission statement, because it is a shared vision and mission [2]. The effects of school improvement that are useful and meaningful for all parties is centered on the development/ built shared vision and mission. When vision and mission were not prepared jointly by the institutions and schools, then there are consequences that arise, such as, statements sentence is less easy to understand, so that there is no similarity in interpreting it [8][1].

At school A and B, the average teachers/staffs are less in memorizing the vision and mission statement. But when they are asked to interpret, they try and interpret it in a language that is almost the same. Average teachers/staffs are more easily recite and interpret the vision, because the statement is in the form of a single sentence. The meaning of the vision and mission of school A has been documented on the pocket book teachers/staffs and the learners personal book. Meanwhile, the meaning of the vision and mission of school B is not explicitly stated on school documents. The meaning of the vision and mission of the school is required to be understood in order to know its characteristics. These characteristics will be demonstrated in the daily practices of teachers/staffs and learners (the school community). It is that the characteristics of the vision and the mission are expected to be reflected in the daily practice of the school community [8].

The characteristics vision and mission statement of the school A has been described in the flowchart "Character Education of Nasima" (artifact code: Ar-A-01), which consists of four parts but is a unity. The flow diagram is indeed there for only about two years ago, because of the development of the school, organizing institutions feel the need to understand the characteristics of the vision and mission of the school. When data collection is done, school A is still in the process of detailing the characteristics of the vision and mission to the indicators of achievement, because earlier indicators of achievement have not been documented. Characteristics of the school B's vision, is specified in the form of indicators of achievement of the vision. The characteristics contained in the vision associated with the words 'forming Khaira Ummah generation'. The indicator is the formation of the younger generation which has the properties of a cadre of Khaira Ummah generation, namely their competences: faith, knowledge, charity, and noble (as in the document of school work plan, document code: Do-B-01 and Do-B-02). Meanwhile, there has been no mention in the document to the characteristics of the mission. What are the characteristics of vision and mission of the school, among which include effective?

Guided by understanding and making the conclusion of several opinions [26][14][12][13][11], about the characteristics of an effective vision and mission for the school as follows.

- Characteristics of an effective vision, namely: a) Concise, simple, realistic, and clear; from the language of the statement as a whole; b) Focus and unique; of contents that lead to the ultimate goal of the organization; c) Challenging, inspiring, and futureoriented; of words that contain the phrase means spirit and foresight.

- Characteristics of effective mission, namely: a) Concise, clear, realistic, and communicative; from the language of the statement; b) Focus and precise; which contents lead to the service goals of the organization; c) Challenging, motivating, and flexible/relevant; of words that contain the phrases of zeal and necessary to be carried out by the organization's members.

Noticing the sentence vision statement of school A, "Guiding Indonesian people to be knowledgeable and possessing Al Karimah Character", it is quite quick and easy to remember/simple. However, that statement contains a meaning that is deep enough. For example, the first word 'guide' is related to all individuals in the school that served to 'guide'. Compiler does not use the word 'educating' or 'teaching', because the meaning of the word 'guiding' is closely related to leading, caring, and guiding itself [10], which further can be meaningfully interpreted as providing care as parents on their children, leading to instruct or giving lessons, and more. Making meaning of vision to get the proper characteristics needs to be supported by the provision of proper understanding.

In the mission statement of the school $\mathrm{A}$, the three sentences are fairly compact, and almost the same as the sentence mission statement, requiring a fairly deep meaning. In general, if the sentence is quite extensive, the focus becomes less, even though it has been able to describe the form of services provided. As in the first sentence, "Holding a quality education" that can be interpreted as the school will provide the 'quality' services in all sections.

While the School B's sentence vision statement, "As Islamic Institute of General Secondary Education leading in educating, deepening, and appreciating Islamic values, and mastery of basics of science and technology to prepare the cadres Khaira Ummah generation"; is relatively long enough to be memorized. The interpretation is quite easy for common people, but still there is a word that needs to be interpreted more deeply. There are seven sentences in the mission statement of the school. A few lines are also quite long, so it is 
quite difficult to memorize, but the thinking is quite clear. The sentences have also been focusing on the form of services provided, for example, the sixth sentence "Creating a culture of Islamic schools".

The similarities in meaning between the sentences of vision in both schools have loaded what is required in National Education Law No. 20 of 2003 on 'whole' education [25]. Both sentence visions have given characteristics that the sentence is structured on the basis of strong religious values, as being expected by the education provider; That the first point of the seven keys to successful education is "build a solid spiritual foundation" [6][3]. These values which have been detailed in the indicators are aimed to develop students character through school programs.

The core of the effectiveness of these characteristics is easily understood and believed by people to be able to be implemented [2][7]. Both schools provide insight into the characteristics of the vision and mission through a joint forum. There is something special for teachers/staff, parents, and students. However, it is still lack of giving an understanding forum done periodically or continuously. In addition, the forum held sometimes not a special forum dedicated to socializing the characteristics of vision and mission, but it is held as the part of the forum meetings with other objectives such as mentoring or professional development of human resources.

The understanding given to the school community is not enough merely about the school's vision and mission. The same understanding or explanation about the objectives to be achieved is needed for the entire school community. In addition to the vision and mission, school $\mathrm{B}$ has been detailing its mission to the school's objective. The details are intertwined in a sentence missions. While the purpose of school A is not yet a coherent details of the mission.

The definition of the different purpose of the vision and mission is that the purpose statement outlining exactly what level of performance to be achieved in the selected domain (for example, learners, educators or professional development) and what steps should be taken, by whom, to achieve the goal. These objectives should be noticeable to be achieved, meaning that the purpose statement is a statement that allows the operation to be executed. The focus and clear school purpose will be more easily understood by the whole school community [8][9]. Therefore, the purpose of the school will be easily expressed if the characteristics of effective vision and mission are known.

Discussing about the condition of schools in developing the capacity to build a vision and mission is not only discussing on the aspects that have been presented. In building the vision and mission, it is initiated by laying the core basic of the vision and mission which is synchronized with the basic/noble values believed by founder/originator institution. The basic values then are set up in the fourth statement of vision, mission, and goals of the school. Wording in the statement of vision, mission, and goals that are less appropriate to the characteristics of the effective vision and mission, requires continuous forms of understanding on all school community.
An understanding of the characteristics of the vision and mission is given to all people in schools through a variety of methods, including doctrinal and socialization at the forum meeting. Efforts of understanding also requires looping delivery, so that the vision and mission that has been detailed in the school and program objectives really understood and be a reflection of the daily habituation of the entire school community. Efforts to build a vision and mission to understand its characteristics are also done through the school culture. School A reflects them through school artifact such as stories, symbols/logo, songs, photo documentation, and so on. Meanwhile, the school B has Islamic School Culture (BuSI program which is used as a means to comprehending the detailed vision and mission in a reflection of the daily activities of the school.

Developing the capacity of school management is ultimately intended to improve the quality of school services. Quality of service is measured by the achievement of the school's vision and mission. It is because essentially, the quality of the school is the quality of the service performance of the organization which is illustrated in the performance of its management. Meanwhile, several studies mention that there is a significant relationship between organizational culture with performance management [5][19][20][17], that a positive or strong culture will improve performance. A positive or strong culture can be a means to build capacity of school management. Both schools have been using it through the school artifacts and programs. The school artifacts and the program is the tool that can be used to spread the culture of the organization.

Organizational culture can be used to build a sense of identity for its members. And through stories, rituals, symbols, and language communication, the coaching of organizational culture is able to be done [21][27]. That a strong culture shows the existence of unified, loyalty, and organizational commitment among members. These cultural forces are associated with performance involving three ideas, the first of which is the existence of objective[21]. At school, objectives are the details of the vision and mission. Meanwhile, the vision and mission are built from the noble values believed by the founder/institution. So it can be said that a strong culture is built by the values adopted and created by the founder/ originator of the institution.

\section{CONCLUSION}

This study originated from the concern of the authors at many schools that cannot take the advantage and the use of the vision and mission as the implementation guidelines for school. Vision, mission and objectives of the school, these three are interlinked. Achieving the vision and mission of the school is the meaning of the quality of school achievement. The expected quality of schools is expressed in the vision and mission statement.

The results showed that the two schools that became the site school have started the building of capacity management that begins with developing a vision and mission. It is focused towards developing management capacity in order to be effective to do. Understanding the characteristics of the vision and mission becomes the important part in it. Sentence 
statement of vision, mission, is arranged on noble values believed by the founders of the institution, and in the process it can be interpreted properly by the entire school community. Understanding of the meaning or the characteristics of the vision and mission is done through the culture of the school, through the vision-mission statement sentences, symbols, slogans, stories, rituals/routines, the language of communication, and so on. Doctrinal or socialization carried out repeatedly by school meant that the understanding of the vision and mission is inherent in the reflection of daily activities.

Students, teachers, staffs, and other school communities that are part of the school's capacity are continuously given an understanding of the characteristics of the vision and mission in which there are noble values espoused by founder/institution. An understanding of the characteristics of the vision and mission is an effort to build a vision and mission. A strong school culture is built on the basis of shared values and created by founder of the institution. Developing the capacity of school management has a strong foundation when the vision and mission of the noble values espoused and was created by the founder of the institution.

\section{ACKNOWLEDGMENT}

Through this article, the author would like to thank the community of Nasima high school and Sultan Agung 1 high school for the cooperation and the willingness to be the location of the research. Hopefully, the later development stages can run well and have an impact on the quality services.

\section{REFERENCES}

[1] Ahanhanzo, J., Odushin, D.E. \& Bibi-Adelakoun, A. Building a Vision for Education in Benin. Prospects, Volume 36, Issue 1, pp 9-21, 2006.

[2] Bainbridge, S. Creating A Vision for Your School, Moving from Purpose to Practice. London : Paul Chapman Publishing, A SAGE Publications Company, 2007

[3] Barna, G. The Power of Vision : Discover and Apply God's Plan for Your Life and Ministry. California, USA : Regal Books, 2009.

[4] Bush, T. The problem with vision . Editorial. Educational Management Administration \& Leadership, Vol. 43(2) 175-176, 2015.

[5] Dizik, A. The Relationship Between Corporate Culture and Performance. The Wall Street Journal, Journal Reports: Leadership, 2016. Accessed from : http://www.wsj.com/articles/the-relationshipbetween-corporate-culture-and-performance-1456110320

[6] Flurry, S. Education with Vision. USA : The Philadelphia Church of God, 2007.

[7] Graham, J. Vision: What's All the Fuss? Choaching Pastors. [Online, 15 Maret 2016]. Accessed from: www.CoachingPastors.com

[8] Gurley, D. et al. Mission, vision, values, and goals: An exploration of key organizational statements and daily practice in schools. Springer Science+ Business Media Dordrecht, Published online : 26 February 2014. [Online, 9 Oktober 2014]. Accessed from : http://link.springer. com/article/10.1007/s10833-014-9229-X.

[9] Hoy, W.K. \& Miskel, C.G. Educational Administration, Theory, Research, and Practice. Eighth edition. New York, USA : The McGrawHill Companies, Inc. 2008.

[10] Kamus Besar Bahasa Indonesia. [Online,19 Maret 2016]. Accessed from : www.kbbi.web.id/bimbing

[11] Kantabutra, S. Vision effects: a critical gap in educational leadership research. International Journal of Educational Management, Vol. 24 Iss: 5, pp.376-390, 2010.

[12] Kantabutra, S. \& Avery, G.C. The Power of Vision: Statements that Resonate. Journal of Business Strategy, Vol. 31 Iss 1 pp. 37-45, 2010.
[13] Kantabutra, S. \& Vimolratana, P. Vision-based leadership : relationships and consequences in Thai and Australian retail stores. Asia-Pacific Journal of Business Administration, Vol. 1 Iss: 2, pp.165-188, 2009.

[14] Khalifa, A.S. "Three Fs for the mission statement: what's next?" Journal of Strategy and Management, Vol. 4 Iss 1 pp. 25-43, 2011.

[15] Koster, W. Restrukturisasi Penyelenggaraan Pendidikan : Studi Kapasitas Sekolah dalam Rangka Desentralisasi Pendidikan, 2001, August. [Online]. Accessed from : https://muhammadalmustofa. wordpress.com/2011/04/03/restrukturisasi-penyelenggaraan-pendidikanstudi-kapasitas-sekolah-dalam-rangka-desentralisasi-pendidikan.

[16] Koster, W. (). Restrukturisasi Penyelenggaraan Pendidikan : Studi Kapasitas Sekolah dalam Rangka Desentralisasi Pendidikan, 2011, April. [Online]. Accessed from : http://www.library.ohiou.edu/indopubs /2001/08/31/0147.html.

[17] Lunenburg, F.C. Organizational Culture-Performance Relationships: Views of Excellence and Theory Z. National Forum of Educational Administration and Supervision Journal, volume 29, number 4, PP.1-10, 2011.

[18] Mario. The Power of Vision. Croatia : CEO (Croatian Evangelistic Outreach), 2005.

[19] Mujeeb E., Tahir M.M., \& Shakil A.M. Relationship between Organizational Culture and Performance Management Practices: A Case of University in Pakistan. Journal of Competitiveness, Issue 4 v3, pp. 78-86. 2011.

[20] Ovidiu-Iliuta, D. The Link Between Organizational Culture and Performance Management Practices : A Case of IT Companies from Romania. The Bucharest University of Economic Studies (Institute of Doctoral Studies, Business Administration), Bucharest, Romania, 2014.

[21] Robbins, S.P. \& Judge, T.A. Organizational Behavior. Fifteenth Edition. USA : Pearson Education, Inc. 2013.

[22] Southern Regional Education Board (SREB). The Three Essentials: Improving Schools Requires District Vision, District and State Support, and Principal Leadership, 2010. [Online, 9 Oktober 2014]. Accessed from : http://www.wallacefoundation.org/knowledge-center/school-leadership/district-policy-and-practice/Documents/Three-Essentials-toImproving-Schools.pdf.

[23] Sumintono, B. Sekolah Unggulan : Pendekatan Pengembangan Kapasitas Sekolah. JMP, Volume 2 Nomor 1, 2013, April.

[24] Triatna, C. Ringkasan Hasil Penelitian : Pengembangan Kapasitas Manajemen Sekolah untuk Meningkatkan Mutu Pendidikan di Sekolah, Studi Kasus di SMA Negeri 2 Kota Bandung dan SMA Negeri 2 Kota Tasikmalaya. Bandung : Program Studi Administrasi Pendidikan, Sekolah Pascasarjana, Universitas Pendidikan Indonesia, 2014.

[25] Undang-undang Republik Indonesia Nomor 20 Tahun 2003 tentang Sistem Pendidikan Nasional.

[26] Wheelen, T.L. \& Hunger, J.D. Strategic Management and Business Policy, Toward Global Sustainability. Thirteenth Edition. USA : Pearson Education, Inc. 2012.

[27] Wibowo. Budaya Organisasi. Jakarta : Rajawali Pers, 2011. 